\title{
DIELECTRIC RELAXATION STUDY OF ETHYL ACRYLATE-ALCOHOL MIXTURES USING TIME DOMAIN REFLECTOMETRY
}

\author{
P. Sivagurunathan ${ }^{\mathrm{a}}$, K. Dharmalingam ${ }^{\mathrm{a}}$, K. Ramachandran ${ }^{\mathrm{a}}$, B. Prabhakar Undre ${ }^{\mathrm{b}}$, \\ P.W. Khirade ${ }^{\mathrm{b}}$, and S.C. Mehrotra ${ }^{\mathrm{c}}$ \\ ${ }^{a}$ Department of Physics, Annamalai University, Annamalai Nagar-608002, Tamilnadu, India \\ E-mail: mukdhar97@rediffmail.com \\ ${ }^{\mathrm{b}}$ Department of Physics, Dr. B.A. Marathwada University, Aurangabad-431004, Maharashtra, India \\ ${ }^{c}$ Department of Electronics and Computer Science, Dr. B.A. Marathwada University, Aurangabad-431004, Maharashtra, \\ India
}

Received 27 September 2006

\begin{abstract}
Dielectric relaxation measurements on ethyl acrylate-alcohol (1-propanol, 1-butanol, 1-hexanol, and 1-octanol) mixtures for different concentrations over the frequency range $10 \mathrm{MHz}-10 \mathrm{GHz}$ have been carried out using time domain reflectometry. Parameters such as the static permittivity, dielectric relaxation time, the Kirkwood correlation factor, and the excess inverse relaxation time were determined and discussed to yield information on the molecular structure and dynamics of the mixture. The values of the dielectric properties decrease with increased ethyl acrylate concentration in alcohol and systematically vary with the alkyl chain length of alcohols. The excess inverse relaxation time values are found to be negative for all concentrations, it may indicate that the effective dipoles of the system rotate slowly.
\end{abstract}

Keywords: dielectric, time domain reflectometry, alcohols, ethyl acrylate

PACS: $77.22 . \mathrm{Ch}, 77.22 . \mathrm{Gm}, 77.84 . \mathrm{Nh}$

\section{Introduction}

Dielectric relaxation study of liquid mixture gives information about molecular interactions. Dielectric relaxation spectroscopy has proven a powerful tool for an investigation of $\mathrm{H}$-bond rearrangement dynamics and has been widely applied for investigating pure solvents, solute-solvent mixtures, supercooled and glass forming liquids, water-organic compound mixtures, and electrolyte solutions. Acrylic esters are important industrial chemicals and are widely used as precursors in the production of technically important high polymeric and latex systems [1]. The production of higher homologues of acrylic esters on an industrial scale is done by transesterification reactions in which an acrylic ester is reacted with an alcohol. Acrylic esters are also most interesting theoretically because they have unsaturation along the side of a carbonyl group in the same molecule. Alcohols play an important role in many chemical reactions due to the ability to undergo selfassociation with manifold internal structures and are in wide use in industry and science as reagents, sol- vents, and fuels and attract great attention as useful solvents in the green technology [2]. Shirke et al. [3,4] reported the dielectric parameters for methyl acetatealcohol and ethyl acetate-alcohol mixtures at different temperatures and concentrations. Patil et al. [5] reported the dielectric parameters for aniline-alcohol mixtures using the time domain technique. Dielectric parameters for dimethylsulphoxide-alcohol and dimethylformamide-alcohol mixtures were reported by Khirade et al. [6,7] using time domain reflectometry (TDR). Chaudari and Mehrotra [8] reported the dielectric parameters for pyridine-alcohol mixtures using TDR. Recently, our research group [9-18] has investigated the complex formation of alkyl methacrylates with proton donors (primary alcohols) in non-polar solvents at $298 \mathrm{~K}$ using Fourier transform infrared (FTIR) spectroscopic method. The complex formation has been interpreted in terms of the association equilibrium constant. Alcohols are associated polar liquids with an $-\mathrm{OH}$ group. Ethyl acrylate is non-associated polar liquid with a $\mathrm{C}=\mathrm{O}$ group. It is interesting to see the nature of interactions between alcohols and ester molecules. 
The aim of the present investigation is to use the dielectric relaxation measurements in the microwave region to study the molecular interaction occurring in liquids through the binary systems of ethyl acrylate with alcohols (1-propanol, 1-butanol, 1-hexanol, and 1-octanol) at $303 \mathrm{~K}$ temperature.

\section{Experimental}

Ethyl acrylate (EA) is an Aldrich product with a manufacturer stated purity of greater than $99 \%$ on a mole basis and is used as such. EA was stabilized with about $0.002 \%$ hydroquinone monomethyl ether. AnalaR grade SD's Fine product of 1-alcohols were purified by standard methods [19]. The solutions were prepared at different volume percentage of ethyl acrylate from 0 to $100 \%$ in steps of $25 \%$.

The complex permittivity spectra were studied using time domain reflectometry. The Hewlett-Packard HP 54750 sampling oscilloscope with HP 54754 A TDR plug-in module was used. A fast rising step voltage pulse of about 39 ps rise time generated by a pulse generator was propagated through a coaxial line system of $50 \Omega$ characteristic impedance. Transmission line system under test was placed at the end of the coaxial line in the standard military application (SMA) coaxial cell connector with $3.5 \mathrm{~mm}$ outer diameter and $1.35 \mathrm{~mm}$ effective pin length.

All measurements were done under open load conditions. The change in the pulse after reflection from the sample placed in the cell was monitored by the sampling oscilloscope. In this experiment, a time window of $5 \mathrm{~ns}$ was used. The reflected pulses without sample $R_{1}(t)$ and with sample $R_{x}(t)$ were digitized in 1024 points in the memory of the oscilloscope and transferred to a PC through a 1.44 MB floppy diskette drive.

A temperature controller system with a water bath and thermostat has been used to maintain the constant temperature of $\approx 273 \mathrm{~K}$ within the accuracy limit. The sample cell was surrounded by a heat-insulating container through which the water of constant temperature from a temperature controller system was circulated. The temperature at the cell is checked using the electronic thermometer.

\section{Data analysis}

The time dependent data were processed to obtain complex reflection coefficient spectra $\rho^{*}(\omega)$ over the

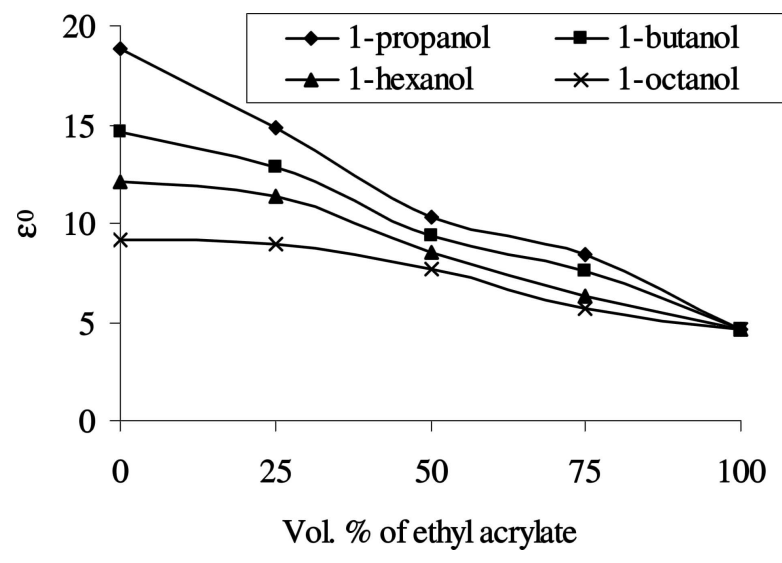

Fig. 1. Static dielectric constant versus volume $\%$ of ethyl acrylate for ethyl acrylate-1-alcohol binary systems.

frequency range from $10 \mathrm{MHz}$ to $10 \mathrm{GHz}$ using Fourier transformation $[20,21]$ as

$$
\rho^{*}(\omega)=\frac{c}{\mathrm{i} \omega d} \frac{p(\omega)}{q(\omega)},
$$

where $p(\omega)$ and $q(\omega)$ are Fourier transforms of $R_{1}(t)-$ $R_{x}(t)$ and $R_{1}(t)+R_{x}(t)$, respectively, $c$ is the velocity of light, $\omega$ is angular frequency, $d$ is the effective pin length, and $i=\sqrt{-1}$.

The complex permittivity spectra $\varepsilon^{*}(\omega)$ were obtained from reflection coefficient spectra $\rho^{*}(\omega)$ by applying a bilinear calibration method [22].

The experimental values of $\varepsilon^{*}$ are fitted with the Debye equation [23]

$$
\varepsilon^{*}(\omega)=\varepsilon_{\infty}+\frac{\varepsilon_{0}-\varepsilon_{\infty}}{1+\mathrm{i} \omega \tau},
$$

with $\varepsilon_{0}, \varepsilon_{\infty}$, and $\tau$ as fitting parameters. A nonlinear least squares fit method [24] was used to determine the values of dielectric parameters.

\section{Results and discussion}

The static dielectric constant $\varepsilon_{0}$ and relaxation time $\tau$ obtained by fitting experimental data with the Debye equation are shown in Figs. 1 and 2. The static dielectric constant for the mixtures increases towards the dielectric constant of the respective alcohol. Increase of dielectric constant is due to the transition of spherical molecular aggregates into elongated aggregates giving rise to parallel orientation of the dipoles. Similar conclusions were drawn by Shirke et al. [4] for ethyl acetate-alcohol systems. This tends to indicate the hetero-interaction which may arise due to the formation of hydrogen bonding between the $-\mathrm{OH}$ group of alcohol molecules and $\mathrm{C}=\mathrm{O}$ of ester molecules. 


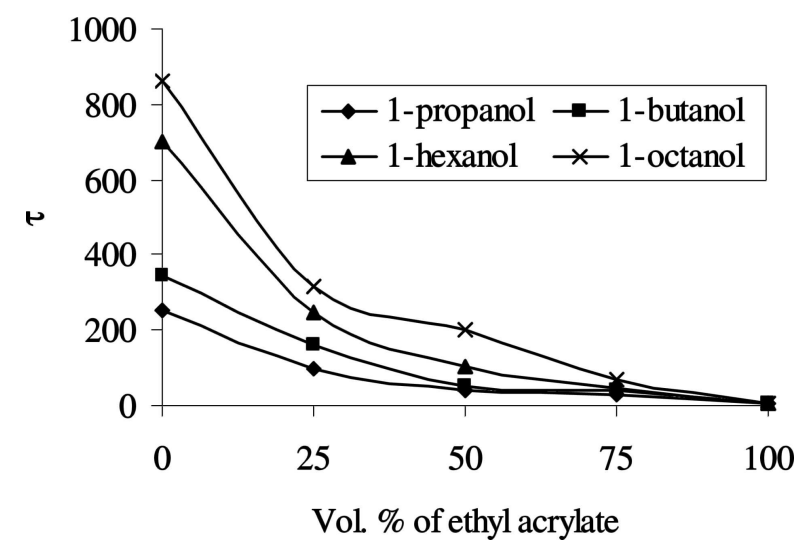

Fig. 2. Relaxation time versus volume \% of ethyl acrylate for ethyl acrylate-alcohol systems.

The decrease in dielectric constant of the solution of higher alcohol is mainly due to greater length of molecules. The relaxation time increases in the case of higher alcohol due to increase in molecular size [25]. There is systematic change in dielectric constant and relaxation time of solution with increase in the concentration of ethyl acrylate in the solution.

The values of static dielectric constant and relaxation time decrease with increased ethyl acrylate concentration in alcohol for all the systems. The decrease in the dielectric constant of the solution with increasing ethyl acrylate concentration and the systematic change in the relaxation time of the solution can be explained on the basis of molecular interactions.

The dielectric relaxation time increases with increasing chain length for these straight chain alcohol molecules, offering hindrance to the rotation of the molecule [25]. It has also been noticed that the $\varepsilon_{0}$ has gradually decreased by increasing the number of carbon atoms in the alkyl chain of alcohols. This trend could be attributed to the decrease in the number of dipoles in the complex, which may lead to a decrease in the molar volume of the rotated molecule [26]. It is also noticed that, though the $\tau$ values of mixtures lie between the individual component values, they are in general different from the averaged value because of the change in the molecular environment and in the size of the relaxing unit. The information related to the solute-solvent interaction is also given by the Bruggeman factor. It shows deviations from linearity for the mixtures of alcohols with ethyl acrylate (Fig. 3). This indicates the interaction existing between the alcohol and ester molecule [27].

The structural information about the liquids from the dielectric relaxation parameter may be obtained using the Kirkwood correlation parameter $g$ [28]. This factor is also a parameter for obtaining information regarding

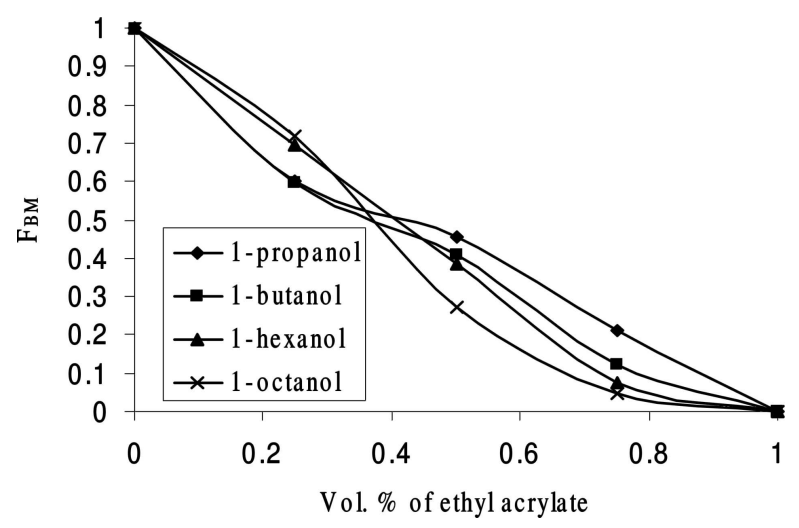

Fig. 3. Bruggeman plot for ethyl acrylate with alcohols.

orientation of electric dipoles in polar liquids. The $g$ for the pure liquid may be obtained using the expression

$$
\frac{4 \pi N \mu^{2} \rho}{9 k T} g=\frac{\left(\varepsilon_{0}-\varepsilon_{\infty}\right)\left(2 \varepsilon_{0}+\varepsilon_{\infty}\right)}{\varepsilon_{0}\left(\varepsilon_{\infty}+2\right)^{2}},
$$

where $\mu$ is the dipole moment in the gas phase, $\rho$ is the density at temperature $T, M$ is the molecular weight, $k$ is the Boltzmann constant, and $N$ is Avogadro's number.

For the mixture of two polar liquids $A$ and $B$, Eq. (3) is modified [29] using the assumption that $g^{\text {eff }}$ is the effective correlation factor in the mixture. The Kirkwood equation for the mixture may be expressed as

$$
\begin{gathered}
\frac{4 \pi N}{9 k T}\left(\frac{\mu_{A}^{2} \rho_{A}}{M_{A}} \Phi_{A}+\frac{\mu_{B}^{2} \rho_{B}}{M_{B}} \Phi_{B}\right) g^{\text {eff }}= \\
\frac{\left(\varepsilon_{0 m}-\varepsilon_{\infty m}\right)\left(2 \varepsilon_{0 m}+\varepsilon_{\infty m}\right)}{\varepsilon_{0 m}\left(\varepsilon_{\infty m}+2\right)^{2}},
\end{gathered}
$$

where $g^{\text {eff }}$ is the effective Kirkwood correlation factor for a binary mixture, with $\Phi_{A}$ and $\Phi_{B}$ as the volume fractions of liquids $A$ and $B$, respectively.

The Kirkwood correlation factor $g^{\text {eff }}$, which provides valuable information about ordering of the molecules in the liquid state, that is, quantifies the extent of polarization of the medium, is plotted in Fig. 4. The $g^{\text {eff }}$ values decrease with increase in concentration of ethyl acrylate in the solution. This indicates that the intermolecular interaction between alcohol and ethyl acrylate decreases with increase in number of acrylate molecules in the solution. The value of $g^{\text {eff }}$ will change from $g_{A}$ to $g_{B}$ as the concentration of $B$ increases from 0 to $100 \% . g^{\text {eff }}$ is an indication of solute-solvent interaction [30].

For the mixtures of ethyl acrylate with each of the four alcohols considered here, the values of $g^{\text {eff }}$ show a decreasing trend with the increasing concentration of 


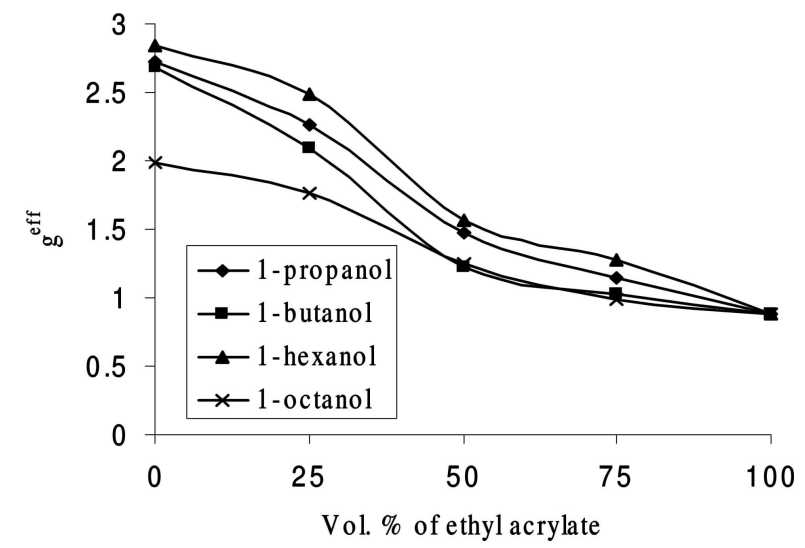

Fig. 4. Kirkwood correlation factor $g^{\text {eff }}$ versus volume $\%$ of ethyl acrylate for ethyl acrylate-alcohol binary systems.

ethyl acrylate in the mixture. This trend suggests reorientation of the neighbouring molecules of the constituent polar liquids forming a tendency towards parallel alignment of dipoles. This conclusion is similar to that arrived at from the variation of dielectric constant with concentration of ethyl acrylate. As a result, weak intermolecular interaction occurs.

The dielectric non-ideality of mixtures suggests a random spatial distribution and orientation. In pure alcohols, a self-correlation of orientation with strong parallel dipolar alignment exists with $g^{\text {eff }}$ values substantially greater than 1 , whereas in ethyl acrylate $g^{\text {eff }}<1$, indicating the correlation is more likely due to a combination of both parallel and antiparallel orientation. On mixing, we find that $g^{\text {eff }}$ is composition dependent and $>1$ for all the systems studied. Hence it appears that, in the mixtures, there arises a need to assign each molecular species a cavity of its own specific volume which in turn determines the molar orientational polarizability. For all the mixtures, the $g^{\text {eff }}$ values are greater than unity, indicating parallel alignment of the electric dipoles.

The information related to solute-solvent interaction may be obtained by excess properties [8] related to the permittivity and relaxation times in the mixture. The excess inverse relaxation time is defined as

$$
\left(\frac{1}{\tau}\right)^{\mathrm{E}}=\left(\frac{1}{\tau}\right)_{m}-\left[\left(\frac{1}{\tau}\right)_{A} x_{A}+\left(\frac{1}{\tau}\right)_{B} x_{B}\right]
$$

where $(1 / \tau)^{\mathrm{E}}$ is the excess inverse relaxation time which represents the average broadening of dielectric spectra. The information regarding the dynamics of solute-solvent interaction from this excess property is as follows:

(i) $(1 / \tau)^{\mathrm{E}}=0$; there is no change in the dynamics of solute-solvent interaction;

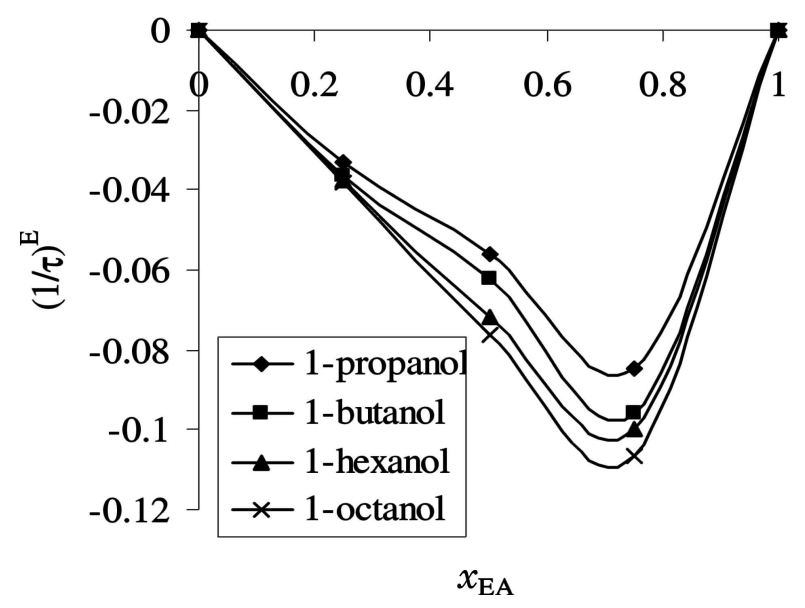

Fig. 5. Excess inverse relaxation time $(1 / \tau)^{\mathrm{E}}$ versus mole fraction $x_{\mathrm{EA}}$ of ethyl acrylate in alcohols.

(ii) $(1 / \tau)^{\mathrm{E}}<0$; the solute-solvent interaction produces a field such that the effective dipoles rotate slowly;

(iii) $(1 / \tau)^{\mathrm{E}}>0$; the solute-solvent interaction produces a field such that the effective dipoles rotate quickly, i. e., the field co-operates in the rotation of the dipoles.

The excess inverse relaxation time values (Fig. 5), negative for all the systems studied, indicate slower rotation of the dipoles, due to the solute-solvent interaction forming the hydrogen bonded structures, which produce a field in such a way that the effective dipole rotation is hindered [31].

\section{Conclusion}

Dielectric relaxation parameters, excess inverse relaxation time, and Kirkwood correlation factor have been reported for ethyl acrylate-alcohol mixtures for various concentrations. These data provide information regarding solute-solvent interaction in liquids. The investigated values of dielectric parameters show systematic change in dielectric values with increase in concentration of ethyl acrylate in the solution. The negative excess inverse relaxation time values indicate slower rotation of effective dipoles of the system. The relaxation time increases with the increase of alkyl chain length of alcohols whereas the reverse trend is observed for static dielectric constant.

\section{References}

[1] C.E. Schildknecht, Vinyl and Related Polymers (Wiley, New York, 1977). 
[2] P.E. Savage, Chem. Rev. Washington, D.C. 99, 603 (1999).

[3] R.M. Shirke, A. Chaudhari, N.M. More, and P.B. Patil, J. Chem. Eng. Data 45, 917 (2000).

[4] R.M. Shirke, A. Chaudhari, N.M. More, and P.B. Patil, J. Mol. Liq. 94, 27 (2001).

[5] S.P. Patil, A. Chaudhari, M.P. Lokhande, M.K. Lande, A.G. Shankarwar, S.N. Helambe, B.R. Arbad, and S.C. Mehrotra, J. Chem. Eng. Data 44, 875 (1999).

[6] P.W. Khirade, A. Chaudhari, J.B. Shinde, S.N. Helambe, and S.C. Mehrotra, J. Chem. Eng. Data 44, 879 (1999).

[7] P.W. Khirade, A. Chaudhari, J.B. Shinde, S.N. Helambe, and S.C. Mehrotra, J. Solution Chem. 28, 1031 (1999).

[8] A. Chaudhari and S.C. Mehrotra, Mol. Phys. 100, 3907 (2002).

[9] P. Sivagurunathan, K. Dharmalingam, and K. Ramachandran, Z. Phys. Chem. 219, 1385 (2005).

[10] K. Dharmalingam and K. Ramachandran, Phys. Chem. Liq. 44, 77 (2006).

[11] P. Sivagurunathan, K. Dharmalingam, and K. Ramachandran, Spectrochim. Acta, Part A 64, 127 (2006).

[12] P. Sivagurunathan, K. Dharmalingam, and K. Ramachandran, Z. Phys. Chem. 219, 1635 (2005).

[13] P. Sivagurunathan, K. Dharmalingam, and K. Ramachandran, Indian J. Pure Appl. Phys. 43, 905 (2005).

[14] P. Sivagurunathan, K. Dharmalingam, and K. Ramachandran, Indian J. Phys. 79, 1403 (2005).

[15] K. Dharmalingam, K. Ramachandran, and P. Sivagurunathan, Z. Phys. Chem. 220, 739 (2006).

[16] K. Dharmalingam, K. Ramachandran, and P. Sivagurunathan, Main Group Chem. 4, 241 (2005).
[17] P. Sivagurunathan, K. Dharmalingam, and K. Ramachandran, J. Solution Chem. 35, 1467 (2006).

[18] K. Dharmalingam, K. Ramachandran, and P. Sivagurunathan, Spectrochim. Acta, Part A (in press).

[19] A.I. Vogal, Text Book of Practical Organic Chemistry, 3rd Ed. (Longman, London, 1957).

[20] H.A. Samulon, Proc. IRE 39, 175 (1951).

[21] C.E. Shannon, Proc. IRE 37, 10 (1949).

[22] R.H. Cole, J.G. Berbarian, S. Mashimo, G. Chryssikos, A. Burns, and E. Tombari, J. Appl. Phys. 66, 793 (1989).

[23] P. Debye, Polar Molecules (The Chemical Catalog Co., Inc., New York, 1929).

[24] P.R. Bevington, Data Reduction and Error Analysis for the Physical Sciences (McGraw-Hill, New York, 1969).

[25] D. Balamurugan, S. Kumar, and S. Krishnan, J. Mol. Liq. 122, 11 (2005).

[26] S.L. Abd-El-Messieh, M.G. Mohamed, A.M. Mazrouaa, and A. Soliman, J. Appl. Polym. Sci. 85, 271 (2002).

[27] P. Sivagurunathan, K. Dharmalingam, K. Ramachandran, B. Prabhakar Undre, P.W. Khirade, and S.C. Mehrotra, Philos. Mag. Lett. 86, 291 (2006).

[28] J.G. Kirkwood, J. Chem. Phys. 7, 911 (1939).

[29] S.M. Puranik, A.C. Kumbharakhane, and S.C. Mehrotra, J. Mol. Liq. 50, 143 (1991).

[30] K. Dharmalingam, K. Ramachandran, P. Sivagurunathan, B. Prabhakar Undre, P.W. Khirade, and S.C. Mehrotra, Mol. Phys. 104, 2835 (2006).

[31] P. Sivagurunathan, K. Dharmalingam, K. Ramachandran, B. Prabhakar Undre, P.W. Khirade, and S.C. Mehrotra, Physica B (in press).

\title{
ETILO AKRILATO IR ALKOHOLIO MIŠINIŲ DIELEKTRINĖS RELAKSACIJOS TYRIMAS, NAUDOJANT LAIKINE REFLEKTOMETRIJA
}

\author{
P. Sivagurunathan ${ }^{\text {a }}$, K. Dharmalingam ${ }^{\text {a }}$, K. Ramachandran ${ }^{\text {a }}$, B. Prabhakar Undre ${ }^{\text {b }}$, P.W. Khirade ${ }^{\text {b }}$, \\ S.C. Mehrotra ${ }^{b}$ \\ ${ }^{\text {a }}$ Anamalai universitetas, Anamalai Nagaras, Tamilnadu, Indija \\ ${ }^{\mathrm{b}}$ Dr. B.A. Marathwada universitetas, Aurangabadas, Maharaštra, Indija
}

\section{Santrauka}

Pateikti etilo akrilato ir alkoholio mišinių (1-propanolio, 1-butanolio, 1-heksanolio ir 1-oktanolio) dielektrinès relaksacijos matavimų duomenys $10 \mathrm{MHz}-10 \mathrm{GHz}$ dažnių ruože, panaudojant reflektometriją laike. Išmatuoti ir aptarti tokie parametrai, kaip statinè dielektrinè skvarba, dielektrinès relaksacijos trukmè, Kirkvudo (Kirkwood) koreliacijos faktorius bei relaksacijos trukmé, kurie leidžia gauti naują informaciją apie molekulių sandarą mišiniuose ir mišinių dinamiką. Atrasta, kad dielektrinè konstanta mažèja, didinant etilo ekrilato koncentaciją alkoholyje, o alkoholio grandinèlių ilgis sistematiškai keičiasi. Rasta, kad perteklinès relaksacijos trukmès vertès yra neigiamos esant visoms koncentracijoms, kas liudija, kad dipoliu sukimasis mišiniuose yra lètas. 